\title{
UPAYA PENINGKATAN MOTORIK KASAR ANAK MELALUI PERMAINAN MAZE SKETCH SPIDER UNTUK ANAK USIA 5-6 TAHUN DI TK BUNGA BANGSA 2 GEROGOL JAYA DEPOK
}

\author{
Mustika Dewi Muttaqien ${ }^{1)}$, Aisyah ${ }^{2)}$ \\ Program Studi Pendidikan Islam Anak Usia Dini \\ Program Sarjana \\ STAI Al-Hamidiyah Jakarta \\ dewimuttaqien@gmail.com ${ }^{1)}$ \\ zenaisyah2@gmail.com $^{2}$
}

\begin{abstract}
Abstrak
Berdasarkan hasil penelitian sebelumnya di TK Bunga Bangsa 2, menunjukkan rendahnya aspek perkembangan motorik kasar anak usia 5-6 tahun disebabkan alat pengembangan motorik kasar anak di TK Bunga Bangsa 2 masih belum maksimal digunakan, dan kurangnya inovasi alat permainan pengembangan motorik kasar anak. Tujuan penelitian ini adalah untuk meningkatkan motorik kasar anak di kelompok B1 TK Bunga Bangsa 2 Gerogol Jaya Depok, dengan menggunakan permainan baru yaitu maze sketch spider. Metode penelitian yang digunakan adalah penelitian tindakan kelas. Sampel diambil sebanyak 15 orang siswa. Pengumpulan data dilakukan dengan observasi langsung dan wawancara dengan guru kelas. Hasil penelitian menunjukkan: 1) Pengamatan pra sikus, pembelajaran belum menggunakan permainan maze dan mencapai nilai rata-rata presentase kelas sebesar 47\%. 2) Pengamatan siklus I, pembelajaran sudah menggunakan permainan maze dan mencapai nilai rata-rata presentase kelas sebesar 58\%. 3) Pengamatan siklus II, mencapai nilai rata-rata presentase kelas sebesar 77\%. Maka berdasarkan hasil penelitian pada siklus II, hasil yang diperoleh sudah mencapai kriteria keberhasilan yang ditentukan sebesar $75 \%$. Oleh karena itu dapat disimpulkan bahwa dengan permainan maze sketch spider, perkembangan motorik kasar anak di Kelompok B1 TK Bunga Bangsa 2 Gerogol Jaya Depok dapat meningkat dengan presentase kelas sebesar $77 \%$.
\end{abstract}

Kata kunci: Motorik Kasar, Permainan, Maze Sketch Spider, Anak.

\begin{abstract}
Based on the results of previous research at Bunga Bangsa 2 Kindergarten, it shows the low aspect of gross motor development for children aged 5-6 years is due to the gross motor development tools for children in Bunga Bangsa 2 Kindergarten are still not optimally used, and the lack of innovation in children's gross motor development games The purpose of this study was to improve the gross motor skills of children in group B1 of TK Bunga Bangsa 2 Gerogol Jaya Depok, by using a new game called maze sketch spider. The research method used is classroom action research. The sample was taken as many as 15 students. Data collection was carried out by direct observation and interviews with class teachers. The results showed: 1) Precycled observations, learning had not used the maze game and reached an average class percentage value of 47\%. 2) Observation cycle I, learning has used the maze game and achieved an average class percentage value of 58\%. 3) Observation cycle II, achieving an average class percentage value of $77 \%$. So based on the results of research in cycle II, the results obtained have reached the specified success criteria of $75 \%$. Therefore it can be concluded that with the maze sketch spider game, the gross motoric development of children in Group B1 of TK Bunga Bangsa 2 Gerogol Jaya Depok can increase with a class percentage of $77 \%$.
\end{abstract}

Keywords: Gross Motoric, Game, Maze Sketch Spider, Children. 


\section{PENDAHULUAN}

Anak usia dini merupakan usia emas atau bisa disebut dengan golden age dimana anak tersebut yang berusia 0 sampai 6 tahun mengalami perkembangan yang sangat signifikan bilamana distimulus dengan benar. Semua aspek perkembangan anak pada usia tersebut mengalami pertumbuhan dan perkembangan yang sangat pesat.

Pendidikan anak usia dini adalah upaya pembinaan dan pangasuhan yang ditujukan bagi anak sejak lahir sampai dengan usia 6 tahun, yang dilakukan melalui pemberian rangsangan pendidikan untuk membantu pertumbuhan dan perkembangan jasmani dan rohani agar anak memiliki kesiapan dalam memasuki pendidikan lebih lanjut.

Perkembangan motorik merupakan salah satu aspek perkembangan yang wajib untuk dikembangkan pada masa pertumbuhan anak, perkembangan motorik kasar yang merupakan perkembangan jasmani melalui kegiatan pusat syaraf dan otot yang terkoordinasi. Pada saat anak berumur 4-5 tahun, anak dapat mengendalikan gerakan secara kasar yang melibatkan bagian badan seperti berjalan, berlari, melompat dan lain sebagainya. Setelah usia 5 tahun perkembangan besar dalam pengendalian koordinasi akan lebih baik dan akan melibatkan otot kecil yang digunakan untuk melempar dan lainlainnya.

Kegiatan motorik kasar adalah suatu pelaksanaan gerak fisik yang menggunakan otot-otot besar pada diri anak yang menjadi dasar untuk bergerak mengikuti seluruh aktivitas dasar lokomotor ataupun nonlokomotor yang tersusun. Melatih gerak motorik kasar anak bisa menggunakan berbagai macam kegiatan dan permainan, seperti: melompat, berjalan, berlari, menendang 
melempar, menangkap, mendorong, memukul, menarik dan lain sebagianya.

Berdasarkan hasil pengamatan Pra Siklus di TK Bunga Bangsa 2, di kelompok B1 terlihat bahwa motorik kasar anak belum berkembang baik, dengan skala presentase kelas sebesar 47\%. Yaitu 11 dari 15 anak yang masih belum berkembang secara optimal motorik kasarnya, Contohnya pada saat anak melompat dengan 2 kaki, masih ada anak yang sering terjatuh karena keseimbanganya belum terbiasa dilatih. Contoh yang lain pada saat bermain, anak-anak sering bermain petak umpet dan tak jarang untuk tidak berlari. Anak-anak pada saat itu berlari dengan temannya tetapi tidak bisa mengontrol gerakan reflek untuk menghindar karena ada orang di depan mereka dan akhirnya tertabrak dan jatuh.

Pada saat wawancara guru kelas kelompok B1, perkembangan motorik kasar di TK Bunga Bangsa 2 biasa menggunakan media bola kecil dan bola besar untuk mengambangkan motorik kasarnya. Selain itu di TK Bunga Bangsa 2 juga menggunakan alat bermain seperti ayunan, tangga pelangi, prosotan, dan lain-lain yang dapat menunjang perkembangan motorik kasarnya. di TK Bunga Bangsa 2 media lain untuk mengembangkan motorik kasar anak masih belum maksimal digunakan, sehingga permainan motorik kasar terkesan monoton.

Perbaikan untuk pengembangan aspek motorik kasar ini haruslah diadakan guna meningkatkan motorik kasar anak di TK Bunga Bangsa 2, khususnya pada kelompok B1 dengan menggunakan pemainan baru yaitu maze sketch spider. Menurut Asni Ariny Haque dan Rohani menyatakan dalam penelitiannya tentang APE maze, menurutnya maze adalah alat yang memiliki bentuk-bentuk dengan tujuan agar orang-orang yang memainkan bisa 
menemukan tempat yang dituju dengan

mencari jejak dan dengan menorehkan

coretan (Enda Sudarmilah, 2016).

Dalam hal ini diharapkan, pengaplikasian permainan maze ini dapat memperbaiki dan meningkatkan motorik kasar anak di TK Bunga Bangsa 2 khususnya pada kelompok B1, dan dengan penggunaan permainan baru ini diharapkan guru menjadi termotivasi dalam membuat permainan pengembangan motorik kasar anak usia dini.

Berdasarkan hasil pengamatan di atas, peneliti akan melaksanakan penelitian tindakan kelas (PTK) dengan menggunakan permainan baru yaitu dengan permainan maze sketch spider, dengan judul penelitian "Upaya Peningkatan Motorik Kasar Anak Melalui Permainan Maze Sketch Spider Untuk Anak Usia 5-6 Tahun Di TK Bunga Bangsa 2 Gerogol Jaya Depok”.

\section{KAJIAN TEORI}

\section{A. Motorik Kasar}

\section{Pengertian Motorik kasar}

Pengertian motorik dan gerak sering kali menjadi satu, hal ini disebabkan karena diantara kedua istilah tersebut sangat sulit ditarik suatu batasan yang konkret. Menurut Prof. Yanuar Kiram, Motorik adalah suatu peristiwa laten yang meliputi keseluruhan proses-proses pengendalian dengan pengaturan fungsi-fungsi organ tubuh baik secara fisiologis maupun secara psikis yang menyebabkan terjadinya suatu gerak. Peristiwaperistiwa laten yang tidak dapat diamati tersebut, antara lain: penerimaan informasi/stimulus, pemberian makna terhadap informasi, pengolahan informasi, proses pengambilan keputusan, dan dorongan untuk melakukan berbagai bentuk aksi-aksi motorik (Yanual Kiram, 2019). 
Jadi motorik dan gerak merupakan dua istilah yang sulit ditarik kesimpulan satu sama lain karena keduanya saling keterkaitan. Motorik dan gerak adalah suatu proses pengendalian dengan pengaturan fungsi organ tubuh baik secara fisiologis maupun secara psikis yang menyebabkan terjadinya suatu gerakan, proses dorongan dalam diri dilakukan untuk melakukan berbagai bentuk aksi-aksi motorik.

Dari uraian di atas, dapat dikatakan bahwa pada masa kanak-kanak merupakan masa yang paling tepat untuk mempelajari keterampilan motorik dikarenakan pada masa tersebut anak masih memiliki ruang dan kesempatan yang luas untuk mempelajari keterampilan-keterampilan motorik jika dibandingkan dengan usiausia lain yang bahkan berbeda di atas usia kanak-kanak.

\section{Faktor}

Pengembangan

\section{Motorik Kasar Anak}

Menurut Ahmad Santoso disebut gerakan kasar, bila gerakan yang dilakukan melibatkan sebagian besar bagian tubuh dan biasanya memerlukan tenaga karena dilakukan oleh otot-otot yang lebih besar. Contoh motorik kasar seperti membalik dan telungkup menjadi telentang atau sebaliknya. Contoh lain gerakan berjalan, berlari, melompat, merangkak, dan lain-lain.

Motorik kasar anak akan berkembang dengan baik apabila diberi kesempatan dan dirangsang oleh lingkungan yang memadai, berikut beberapa kondisi yang dapat merangsang laju perkembangan motorik anak secara umum, antara lain:

a. Faktor genetik dalam bentuk tubuh dan inteligensi. Anak yang mempunyai bentuk tubuh yang normal (atletis) dan dalam tingkat inteligensi yang tinggi umumnya 
perkembangan motoriknya lebih

pesat dibandingkan dengan mereka

yang berinteligensi menengah atau

di bawah rata-rata.

b. Janin yang aktif cenderung menjadi anak yang aktif, kecuali ada hambatan lain setelah proses kelahiran.

c. Kondisi janin ketika dalam kandungan yang aman dalam arti segala terpenuhi baik kesehatan, gizi, psikologis, dan segala perlakuan yang memungkinkan bayi berkembang lebih baik.

d. Adanya dukungan, keseimbangan dan stimulus, sebagai contoh anak sulung berkembang lebih cepat daripada anak berikutnya karena dukungan dan stimulus orangtua lebih intens.

e. Kondisi yang menghambat perkembangan motorik kasar anak, seperti kelahiran dengan bantuan alat, seperti vacum dan kelahiran sulit lain yang dibarengi oleh trauma kepala, kelahiran premature dan cacat fisik seperti kebutaan atau tuli (Ahmad Santoso, 2015).

Maka dari itu, beberapa kondisi di atas sangat mempengaruhi laju perkembangan motorik kasar anak seperti faktor genetik anak, terpenuhi dalam hal gizi yang dibutuhkan anak, dan didukung oleh stimulus untuk meningkatkan keterampilan motorik kasar anak.

\section{Tujuan}

\section{Pengembangan}

\section{Motorik Kasar Anak}

Tujuan utama dari pengembangan motorik kasar ialah agar anak dapat menguasai lingkungan melalui peningkatan dari control tubuh dan pengembangan sikap, pengetahuan, keterampilan dan perilaku-perilaku yang berhubungan dalam memelihara, menghormati, dan melindungi tubuh mereka. Di bawah merupakan tujuantujuan objektif untuk mencapai tujuan 
utama sehingga anak mempunyai

kesempatan untuk:

a. Dapat menggunakan tubuh mereka dengan penuh percaya diri.

b. Mengembangkan kesadaran tentang lokasi dari bagian-bagian tubuh mereka sendiri.

c. Mengembangkan

kesadaran terhadap ruang (memahami ruang dari diri dan umum serta arah).

d. Terlibat dalam macam-macam kegiatan yang membutuhkan keseimbangan.

e. Terlibat dalam kegiatan yang membutuhkan gerakan-gerakan koordinasi.

f. Mempertahankan aktivitas motorik badan terus-menerus untuk dapat mengembangkan daya tahan tubuh.

g. Terlibat dalam macam-macam kegiatan yang membutuhkan kelenturan. h. Terlibat dalam kegiatan-kegiatan motorik yang membutuhkan ketangkasan.

i. Menggunakan seluruh tubuh mereka dalam kegiatan-kegiatan yang sesuai untuk memperkuat atot dan kelompok-kelompok otot.

j. Mengembangkan keterampilanketerampilan motorik dasar seperti melompat dengan 2 kaki, melompat dengan satu kaki, melempar, menendang, memukul, nerlari, atau menangkap.

k. Melakukan koordinasi jari, jari telunjuk-ibu jari, dan gerakan matatangan.

1. Mengontrol gerakan dari tubuh mereka dalam hubungannya dengan benda-benda.

m. Menggunakan tubuh mereka untuk menggerakkan atau engubah bendabenda.

n. Mengembangkan sikap positif tentang tubuh mereka. 
o. Belajar bagaimana untuk menjaga tubuh mereka tetap bersih.

p. Belajar bagaimana untuk menjaga tubuh mereka tetap sehat.

q. Belajar dan berlatih untuk mempunyai kebiasaan untuk makan makanan sehat.

r. Belajar untuk mengikuti prosedur yang aman di sekolah, rumah, dan lingkungan sekitasnya.

s. Membedakan antara hidup sehat dan tidak sehat seta latihan tentang keamanan.

t. Belajar bagaimana untuk menerapkan pengetahuan hidup sehat dan aman dalam membuat pilihan di kehidupan sehari-hari (Mukhtar Latif, Zukhairina, Rita Zubaidah, Muhammad Afandi, 2013:64).

Penguasaan keterampilan yang terlihat dalam kemampuan menyelesaikan tugas motorik tertentu yang diberikan oleh guru merupakan salah satu tujuan pengembangan motorik kasar anak. Kualitas motorik anak dapat dilihat dari seberapa jauh kemampuan yang anak lakukan pada saat melaksanakan tugas motorik dengan tingkat keberhasilan yang telah ditentukan.

\section{Capaian Pengembangan}

\section{Motorik Kasar Anak}

Tingkat pencapaian perkembangan menggambarkan pertumbuhan dan perkembangan yang diharapkan tercapai terhadap anak dalam rentang usia tertentu. Dibawah ini merupakan tingkat pencapaian perkembangan motorik anak dengan retang usia 4-6 tahun menurut Peraturan Menteri Pendidikan Dan Kebudayaan Republik Indonesia No. 137 Tahun 2014 tentang Standar Nasional Pendidikan Anak Usia Dini (Permendikbud No 137, 2014), yaitu:

Tabel 2.1 


\section{Standar Isi Tentang Tingkat Pencapaian Perkembangan Anak}

\begin{tabular}{|c|c|c|}
\hline \multirow{2}{*}{$\begin{array}{c}\text { Lingkup } \\
\text { Perkembangan }\end{array}$} & \multicolumn{2}{|c|}{ Tingkat Pencapaian Perkembangan } \\
\hline & Usia 4 - $<5$ tahun & Usia 5 - $\leq 6$ tahun \\
\hline Motorik Kasar & $\begin{array}{l}\text { 1. Menirukan gerakan } \\
\text { binatang, pohon tertiup } \\
\text { angin, pesawat } \\
\text { terbang, dsb. } \\
\text { 2. Melakukan gerakan } \\
\text { menggantung } \\
\text { (bergelayut). } \\
\text { 3. Melakukan gerakan } \\
\text { melompat, meloncat, } \\
\text { dan berlari secara } \\
\text { terkoordinasi } \\
\text { 4. Melempar sesuatu } \\
\text { secara terarah } \\
\text { 5. Menangkap sesuatu } \\
\text { secara tepat } \\
\text { 6. Melakukan gerakan } \\
\text { antisipasi } \\
\text { 7. Menendang sesuatu } \\
\text { secara terarah } \\
\text { 8. Memanfaatkan alat } \\
\text { permainan di luar } \\
\text { kelas. }\end{array}$ & $\begin{array}{l}\text { 1. Melakukan gerakan } \\
\text { tubuh secara } \\
\text { terkoordinasi untuk } \\
\text { melatih kelenturan, } \\
\text { keseimbangan, dan } \\
\text { kelincahan. } \\
\text { 2. Melakukan koordinasi } \\
\text { gerakan mata-kaki- } \\
\text { tangan-kepala dalam } \\
\text { menirukan tarian atau } \\
\text { senam. } \\
\text { 3. Melakukan permainan } \\
\text { fisik dengan aturan. } \\
\text { 4. Terampil } \\
\text { menggunakan tangan } \\
\text { kanan dan kiri. } \\
\text { 5. Melakukan kegiatan } \\
\text { kebersihan diri. }\end{array}$ \\
\hline
\end{tabular}

Dari table di atas menunjukan, bahwa anak dalam lingkup usia 5-6 tahun memiliki kriteria capaian seperti kelenturan, keseimbangan, dan kelincahan dari segi gerakan tubuh dan dapat melakukan gerakan fisik dengan aturan yang dipakai saat bermain, dan tidak lupa dalam menjaga kebersihan diri. 
5. Karakteristik Perkembangan Motorik Kasar Anak

Menurut Magill Richard A. di dalam jurnal Sajidan, pembagian keterampilan motorik adalah berdasarkan kecermatan dalam melakukan gerakan keterampilan dibagi menjadi dua yaitu keterampilan motorik kasar (gross motor skill) dan keterampilan motorik halus (fine motor skill). Keterampilan motorik kasar (gross motor skill) merupakan keterampilan gerak yang menggunakan otot-otot besar, tujuan kecermatan gerakan bukan merupakan suatu hal yang penting akan tetapi koordinasi yang halus dalam gerakan adalah hal yang paling penting (Sajidan, 2008).

Karakteristik pengembangan motorik kasar anak memiliki kriteria keterampilan koordinasi motorik kasar meliputi kegiatan seluruh tubuh atau sebagian tubuh. Keterampilan koordinasi motorik kasar mencakup ketahanan, kecepatan, kelenturan, ketangkasan, keseimbangan dan kekuatan. Keterampilan koordinasi motorik kasar dapat dibagi kedalam tiga kelompok, yaitu (Dadan Suryana, 2016):

a. Keterampilan lokomotor, meliputi gerak tubuh yang berpindah tempat yaitu: berjalan, berlari, melompat, meluncur, berguling, menderap, menjatuhkan diri, dan bersepeda. Keterampilan lokomotor membantu mengembangkan kesadaran anak akan tubuhnya dalam ruang. Kesadaran ini disebut kesadaran persepsi motorik yang meliputi kesadaran akan tubuh sendiri, waktu hubungan ruang (spasial), konsep arah, visual, dan pedengaran.

b. Keterampilan nonlokomotor, yaitu menggerakkan anggota tubuh dengan posisi tubuh diam di tempat, seperti: berayun, 
mengangkat,

bergoyang,

merentang, memeluk, melengkung,

memutar,

membungkuk,

mendorong. Keterampilan ini

sering dikaitkan dengan

keseimbangan atau kestabilan

tubuh, yaitu gerakan yang

membutuhkan keseimbangan pada

taraf tertentu.

c. Keterampilan

manipulative,

meliputi penggunaan serta

pengontrolan gerakan otot-otot

kecil yang terbatas, terutama yang

berada di tangan dan kaki.

Keterampilan

gerakan

manipulative, antara lain meregang,

memeras, menarik, menggenggam,

memotong, meronce, membentuk,

menggunting, dan menulis.

Keterampilan memproyeksi,

menangkap, dan menerima,

keterampilan ini dapat dilihat pada

waktu anak menangkap bola,

menggiring bola, melempar bola, menendang bola, melambungkan

bola, memukul dan menarik.

Sesuai dengan tujuan pendidikan di taman kanak-kanak yang mengembangkan seluruh aspek perkembangan, maka yang dilakukan pendidik adalah mengembangkan jasmani anak dan bukan mengajarkan olahraga. Pengembangan jasmani pada anak TK menitikberatkan pada latihan gerak yang sifatnya informal dan bebas sehingga anak dapat menguasai gerakan-gerakan dasar yang diperlukan untuk pertumbuhan dan perkembangan diri selanjutnya.

\section{B. Permainan Maze Sketch Spider}

\section{Pengertian Permainan}

Bermain atau "play" merupakan setiap kegiatan yang dilakukan untuk kesenangan yang ditimbulkan, tanpa mempertimbangkan hasil akhir. Bermain dilakukan secara suka rela dan tidak ada paksaan atau tekanan dari luar atau kewajiban. Menurut Anggani 
Sudono, bermain adalah suatu kegiatan yang dilakukan dengan atau tanpa mempergunakan alat yang menghasilkan pengertian atau memberikan informasi, memberi kesenangan maupun mengembangkan imajinasi pada anak (Anggani Sudono, 2000).

Pada masa kanak-kanak sangat cocok untuk menggunakan pembelajaran menggunakan permainan, karena dari permainan terbentuklah kepribadian dan bermain adalah aktifitas murni yang dimiliki anak tanpa memikirkan menang atau kalah. Bermain secara garis besar dapat dibagi menjadi 2 kategori, yaitu:

a. Bermain aktif, kesenangan timbul dari apa yang dilakukan individu, apakah dalam bentuk kesenangan berlari atau membuat sesuatu kesenangan berlari atau membuat sesuatu dengan lilin atau cat. Anakanak kurang melakukan kegiatan bermain secara aktif ketika mendekati masa remaja dan mempunyai tanggung jawab lebih besar di rumah dan di sekolah serta kurang bertenaga karena pertumbuhan pesat dan perubahan tubuh.

b. Bermain pasif atau 'hiburan', kesenangan diperoleh dari kegiatan orang lain. Pemain menghabiskan sedikit energi. Anak yang menikmati temannya bermain, memandang orang atau hewan di televisi, menonton adegan lucu atau membaca buku adalah bermain tanpa mengeluarkan banyak tenaga, tetapi kesenangannya hampir seimbang dengan anak yang menghabiskan sejumlah besar tenaganya di tempat olah raga atau tempat bermain (Elizabeth B. Hurlock, 1978).

Pengamatan ketika anak bermain secara aktif maupun pasif, akan banyak 
membantu memahami jalan pikiran anak, selain itu juga akan meningkatkan keterampilan berkomunikasi.

\section{Karakteristik Permainan}

Ketika belajar keterampilan gerak, yang menjadi objek yang dipelajari adalah bentuk-bentuk keterampilan gerak itu sendiri. Untuk dapat menguasai bentuk-bentuk keterampilan gerak yang dimaksud, maka sebelumnya diberikan pengetahuanpengetahuan tentang apa dan bagaimana keterampilan gerak yang dipelajari. Setelah itu dilanjutkan dengan latihanlatihan dalam bentuk aktivitas fisik yang diarahkan pada penguasaan keterampilan gerak yang diinginkan.

Berdasarkan penelitian yang dilakukan oleh Smith, Garvery, Rubin, Fein dan Vandenberg diungkapkan adanya beberapa ciri kegiatan bermainan, yaitu sebagai berikut:

a. Dilakukan berdasarkan motivasi intrinsik, maksudnya muncul berdasarkan keinginan pribadi serta untuk kepentingan sendiri.

b. Perasaan dari orang yang terlibat dalam kegiatan bermain diwarnai oleh emosi-emosi yang positif. Kalaupun emosi positif tidak tampil, setidaknya kegiatan bermain mempunyai nilai bagi anak.

c. Fleksibilitas yang ditandai mudahnya kegiatan beralih dari satu aktivitas ke aktivitas lain.

d. Lebih menekankan pada proses yang berlangsung dibandingkan hasil akhir. Saat bermain, perhatian anak-anak lebih terpusat pada kegiatan yang berlangsung dibandingkan tujuan yang ingin dicapai.

e. Bebas memilih dan ciri ini merupakan elemen yang sangat penting bagi konsep bermain pada anak usia dini. 
f. Mempunyai kualitas fantasi yang tinggi. Kegiatan bermain mempunyai kerangka tertentu yang memisahkannya dari kehidupan nyata sehari-hari. Kerangka ini berlaku terhadap semua bentuk kegiatan bermain, seperti bermain peran, menyusun balok, menyusun kepingan puzzle dan lainnya. Realitas internal lebih diutamakan dari pada realitas eksternal, karena anak memberi 'makna' baru terhadap objek yang dimainkan dan mengabaikan keadaan objek yang sesungguhnya. Keadaan ini bisa kita simak saat anak bermain, tindakan anak akan berbeda dengan perilakunya saat sedang tidak bermain (Andang Ismail, 2009).

Berdasarkan uraian di atas dapat dikatakan bahwa karakteristik bermain memiliki beberapa ciri yaitu bermain karena keinginan diri sendiri tidak dipaksa, fleksibel dalam memilih permainan atau bebas memilih dan mempunyai kualitas fantasi yang tinggi.

\section{Tahapan Perkembangan}

\section{Bermain Anak}

Tahapan bermain (Play Stage) biasanya terjadi bersamaan dengan mulai masuknya anak ke sekolah dasar. Pada masa ini jenis permainan anak semakin bertambah banyak, karena itu tahap ini dinamakan tahap bermain anak. Dian Apriani (2016) menyatakan dalam penelitiannya yang mengutip Yuliani, menurutnya ada enam tahapan perkembangan pada anak, yaitu:

a. Unoccupied atau tidak menetap, Anak hanya melihat anak lain bermain, tetapi tidak ikut bermain. Anak pada tahap ini hanya mengamati sekeliling dan berjalanjalan, tetapi tidak terjadi interaksi dengan anak yang bermain.

b. Onlooker atau penonton/pengamat, Pada tahap ini anak belum mau terlibat untuk bermain, tetapi anak 
sudah mulai bertanya dan lebih mendekat pada anak yang sedang bermain dan anak sudah mulai muncul ketertarikan untuk bermain. Setelah mengamati anak biasanya dapat mengubah cara bermainnya.

c. Solitary independent play/bermain sendiri, Tahap ini anak sudah mulai bermain, tetapi bermain sendiri dengan mainannya, terkadang anak berbicara dengan temannya yang sedang bermain, tetapi tidak terlibat dengan permainan anak lain.

d. Parallel Activity/Kegiatan Paralel, Anak sudah bermain dengan anak lain tetapi belum terjadi interaksi dengan anak lainnya dan anak cenderung menggunakan alat yang ada didekat anak yang lain. Pada tahap ini anak juga tidak mempengaruhi anak lain dalam bermain dengan permainannya.

e. Associative Play/Bermain dengan teman, Pada tahap ini terjadi interaksi yang lebih kompleks pada anak. Dalam bermain anak sudah mulai saling mengingatkan satu sama lain. Terjadi tukar menukar mainan atau anak mengikuti anak lain. Meskipun anak dalam kelompok melakukan kegiatan yang sama, tidak terdapat aturan yang mengikat dan belum memiliki tujuan khusus atau belum terjadi diskusi untuk mencapai tujuan bersama.

f. Cooperative or organized supplementary play/kerjasama dalam bermain atau dengan aturan, Saat anak bermain bersama secara lebih terorganisasi dan masingmasing menjalankan peran yang saling mempengaruhi satu sama lain. Anak bekerjasama dengan anak lain untuk membangun sesuatu, terjadi persaingan, membentuk permainan drama dan biasanya dipengaruhi oleh anak 
yang memiliki pengaruh atau adanya pemimpin dalam bermain.

\section{Manfaat Bermain Bagi Anak}

Bermain mengandung aspek kegembiraan, kelegaan, kenikmatan yang intensif, bebas dari ketegangan atau kedukaan, bersifat memerdekakan jiwa. Permainan manusia sangat erat dengan ekspresi diri, spontanitaas, melatih pribadi untuk siap melewati persaingan, siap menerima kekalahan, dan aktualisasi diri.

Bermain merupakan hal yang penting bagi anak, kerena diusia tersebut anak dapat belajar dari apa-apa yang telah ia alami. Berikut adalah beberapa manfaat bermain bagi anak, yaitu:

a. Sarana untuk membawa anak ke alam bermasyarakat. Dalam suasana permainan mereka saling mengenal, saling menghargai satu dengan lainnya, dan dengan perlahan-lahan tumbuhlah rasa kebersamaan yang menjadi landasan bagi pembentukan perasaan sosial.

b. Untuk mengenal kekuatan sendiri. Anak-anak yang sudah terbiasa bermain dapat mengenal kedudukannya dikalangan temantemannya, dapat mengenal bahan atau sifat-sifat benda yang mereka mainkan.

c. Untuk memperoleh kesempatan mengembangkan fantasi dan menyalurkan kecenderungan pembawaannya. Jika anak laki-laki dan anak perempuan diberi bahanbahan yang sama berupa kertas, perca (sisa kain), dan gunting, tampaknya mereka akan membuat sesuatu yang berbeda. Hal ini membuktikan bahwa anak laki-laki berbeda bentuk-bentuk permianannya dengan permainan anak perempuan. 
d. Dapat melatih menempa emosi. kemampuan sosialnya yang akan

Ketika bermain mereka mengalami bermacam-macam perasaan. Ada anak yang dapat menikmati suasana permainan, sebaliknya sebagian anak yang lain kecewa. Keadaan ini diumpamakan dengan seniman yang sedang menikmati hasil karya masing-masing.

e. Untuk memperoleh kegembiraan, kesenangan, dan kepuasan. Suasana kegembiraan dalam permainan dapat menjaukan diri dari perasaan rendah, misalnya perasaan dengki, iri hati, dan sebagainya.

f. Melatih diri untuk mentaati peraturan yang berlaku. Mereka mentaati peraturan yang berlaku dengan penuh kejujuran untuk menjaga agar tingkat permainan tetap tinggi (Dian Aprilia, 2016).

Berdasarkan uraian di atas, dapat ditegaskan bahwa melalui bermian anak berkesempatan untuk mengembangkan membawanya bermasyarakat, mengenal kemampuan diri sendiri apa yang anak kuasai atau yang belum dikuasai, dan melatih emosi anak dalam bermain. Kegiatan ini sendiri merupakan suatu proses dinamis dimana seorang anak memperoleh informasi dan pengetahuan yang kelak dijadikan landasan dasar pengetahuannya dalam proses belajar berikutnya dikemudian hari.

\section{Permainan Maze Sketch Spider}

Alat permainan edukatif ada bermacam-macam salah satunya yaitu permainan maze. Menurut Ahmad Mushlih, S.Pd, dkk, maze memiliki pengertian mencari jejak, jika disekolah biasa hanya berbentuk gambar kemudian anak menemukan jalan menuju tujuan yang dimaksud. Di sekolah yang berbasis alam mencari jejak bisa memanfaatkan alam untuk mempraktekkan mencari sesuatu yang dimaksud oleh guru dan anak sebagai 
pelaku secara langsung mencari di alam

atau taman atau lapangan terbuka

(Ahmad Mushlih, 2018).

Asni Ariny Haque dan Rohani menyatakan dalam penelitiannya tentang APE maze, menurutnya maze adalah alat yang memiliki bentukbentuk dengan tujuan agar orang-orang yang memainkan bisa menemukan tempat yang dituju dengan mencari jejak dan dengan menorehkan coretan (Endah Sudarmilah, 2016).

Dapat dikatakan maze merupakan game sederhana yang bertujuan menentukan jalur yang tepat dan mencapai tujuan yang telah ditetapkan. Maze sketch spider adalah permainan modifikasi dari permainan maze itu sendiri. Dalam permainan edukatif maze sketch spider ini, anak-anak harus menemukan beberapa jalur pada bagianbagian maze berupa bentuk gambar yang memiliki arti di dalam gambar tersebut. Setelah anak memulai permainan, anak diminta untuk melakukan gerakan sederhana seperti melompat, berjalan dan lain-lain.

Maze sketch spider merupakan salah satu bentuk permainan yang menyenangkan dan salah satu inovasi baru dalam mengembangkan aspek perkembangan terutama aspek motorik kasar anak.

Permainan maze sketch spider ini, bermanfaat untuk mengembangkan semua aspek perkembangan anak, yaitu:

a. Perkembangan kognitif, misal anak mampu mencari jalan yang sangat efektif untuk bisa sampai ke tujuan yang diinginkan, perkembangan afektif, anak mampu mengetahui tempat mana yang bisa digunakan untuk menunaikan ibadah.

b. Perkembangan motorik, anak mampu mengikuti jalan liku-liku untuk bisa sampai dari suatu tempat ke tempat yang lain. 
c. Perkembangan seni, anak mampu memilih jalan yang lebih cepat untuk bisa sampai ke suatu tempat tujuan.

d. Perkembangan bahasa, anak mampu berinteraksi dengan temannya untuk bisa berangkat ke tempat yang ingin dituju.

e. Perkembangan sosial emosional, anak mampu membantu temannya mencari jalan untuk menuju ke suatu tempat.

Permainan maze sketch spider sangat bermanfaat untuk mengajarkan gerakan beserta fungsi dan kegunaannya. Adapun beberapa manfaat dari permainan ini, yaitu:

a. Mempermudah guru dalam pembelajaran di kelas.

b. Membuat peserta didik senang dan tidak cepat bosan dalam mengikuti dan menerima pelajaran. c. Memperkuat kelenturan tubuh peserta didik tentang gerak, fungsi dan kegunaannya.

\section{Langkah-Langkah Bermain}

\section{Maze Sketch Spider}

\section{a. Tahap Persiapan}

1) Siapkan gambar yang sudah dibuat oleh guru.

2) Tempel di lorong utama sekolah atau bila dikelas cukup luas ruangannya bisa diaplikasikan di dalam kelas.

\section{b. Tahap Permainan}

1) Murid diajak untuk membuat lingkaran sembari menunggu giliran dipanggil untuk mengikuti kegiatan.

2) Guru tetap memegang kendali

3) Beri contoh terlebih dahulu kepada murid, cara bermain permainan 
tersebut dan tata tertib permainan.

4) Setelah murid paham semua, selanjutnya murid diajak untuk melakukan permainan tersebut dengan bergantian di lorong utama sekolah sebanyak 2 kali.

5) Selesai.

\section{METODOLOGI PENELITIAN}

Jenis Penelitian ini merupakan Penelitian Tindakan Kelas (PTK). Subjek penelitian ini adalah kelompok B1 TK Bunga Bangsa 2 Gerogol Jaya Depok, dengan rentang usia 5-6 tahun dan objek penelitian adalah motorik kasar anak. Penelitian tindakan kelas yang digunakan dalam penelitian ini adalah penelitian yang mengacu pada model Kemmis \& Mc. Taggart. Pelaksanaan penelitian tindakan kelas ini didesain model dari Kemmis \& $M c$. Taggart yang perangkatnya terdiri atas empat komponen, yaitu planning (perencanaan), acting (tindakan), observing (pengamatan), dan reflecting (refleksi). Pelaksanaan penelitian dilaksanakan sebanyak dua siklus, masing-masing siklus dilaksanakan selama 4 hari dimulai dari jam 08.0010.30 WIB. Siklus I dilaksanakan pada tanggal 13 Mei-16 Mei 2019, sedangkan siklus II dilaksanakan pada 20 Mei-23 Mei 2019. Metode pengumpulan data yang digunakan dalam penelitian ini adalah observasi dan wawancara, dokumentasi.

\section{HASIL PENELITIAN}

Pengamatan pra siklus dilakukan pada tanggal 10-12 April 2019. Berdasarkan hasil pengamatan Pra Siklus di TK Bunga Bangsa 2 kelompok B1 terlihat bahwa motorik kasar anak belum berkembang baik, dengan skala presentase kelas sebesar 47\%. Yaitu 11 
dari 15 anak yang masih belum berkembang secara optimal motorik kasarnya.

Berdasarkan permasalahan tersebut, perlu dilakukan tindakan nyata untuk meningkatkan kemampuan motorik kasar anak agar kemampuan anak dapat tercapai. Usaha yang dilakukan peneliti dan guru untuk meningkatkan kemampuan motorik kasar anak ialah dengan melakukan kegiatan bermain maze sketch spider pada kelompok B1 TK Bunga Bangsa 2. Melalui tindakan yang dilakukan oleh peneliti diharapkan dapat meningkatkan kemampuan motorik kasarnya.

\section{1) Perencanaan}

Penelitian dilakukan pada hari Senin, tanggal 13 Mei 2019. Rencana pelaksanaan pembelajaran harian (RPPH) disusun oleh peneliti. RPPH disusun dengan indikator yang sesuai dengan tema alam semesta dan sub tema benda-benda alam. Pada kegiatan awal peneliti akan membuat kegiatan pengembangan motorik kasar seperti 'menirukan gerakan pesawat terbang'. Pada kegiatan inti peneliti memasukkan kegiatan permainan 'maze sketch spider' untuk dimasukkan ke dalam salah satu kegiatan. Pada kegiatan akhir peneliti menutup kegiatan dengan menyanyikan 'siapa suka hati lompat tinggi'.

Peneliti dan kolaborator (guru kelas) sepakat bahwa kegiatan pembelajaran tetap dilaksanakan seperti biasa, hanya pada pelaksanaan tindakan penelitian dilakukan pada kegiatan awal karena berupa kegiatan fisik. Peneliti menyiapkan media berupa permainan maze sketch spider, menyiapkan lembar observasi, dan alat untuk mendokumentasikan pembelajaran berupa kamera.

\section{2) Tindakan}

1. Kegiatan Pengembangan I (Pembukaan) 


Guru mengajak anak
untuk 'menirukan gerakan
pesawat terbang'. Pada saat anak
selesai berbaris di halaman
sekolah, guru kelas mengajak
anak untuk masuk kelas
menggunakan gerakan pesat
tebang. Seperti rentangkan
kedua tangan menyerupai sayap
pesawat kemudian berjalan
hingga masuk kelas sambil
bernyanyi 'pak pilot'.
2. Kegiatan Pengembangan II
(Inti)

Anak berbaris di luar kelas sambil guru menjelaskan cara bermain maze sketch spider. Langkah-langkah pelaksanaan :

- Guru mempraktikkan gerakan permainan maze sketch spider.
- Anak bergantian memainkan permainnan maze sketch spider.

- Anak memiliki 2 kali kesempatan untuk memainkan maze sketch spider.

3. Kegiatan Pengembangan III (Penutup) Anak-anak berdiri membentuk melingkar, kemudian guru berdiri diantara anak-anak. Guru memberi contoh tepuk siapa senang hati lompat tinggi, kemudian anak satu persatu mengikuti gerakan guru. Hingga semua anak mengikuti perintah nyanyian yang di lantunkan guru.

\section{3) Pengamatan}

Berdasarkan pengamatan peneliti, dapat diketahui bahwa hasil 
penilaian anak pada kegiatan bermain maze sketch spider didapatkan hasi: ada

11 anak mendapatkan nilai mulai berkembang, dan 4 anak mendapatkan nilai berkembang sesuai harapan.

\section{4) Refleksi}

Refleksi pada kegiatan pengembangan yang telah dilakukan pada RPPH siklus I di kegiatan inti adalah bermain maze sketch spider. Antusias anak dalam mengikuti kegiatan dari awal hingga akhir sangat tinggi, tetapi dari semua kegiatan di atas masih terdapat kelemahan-kelemahan yang harus diperbaiki pada siklus ke-2.

Pada saat kegiatan inti, guru menerangkan gerakan-gerakan permainan maze tetapi masih ada beberapa anak yang masih kaku pada saat praktiknya. Pada saat siklus ke-2 nanti guru mengajak anak untuk terlebih dahulu melakukan pemanasan, sehingga pada saat bermain tubuh anak menjadi lebih lentur dari sebelumnya.

\section{B. Pembahasan}

Berdasarkan pengamatan hasil pra siklus untuk dijadikan acuan dalam siklus I, didapati peningkatan kemampuan motorik kasar anak. Pengamatan dilakukan dengan menggunakan instrument penilaian berupa lembar observasi. Berikut data perkembangan anak pada kegiatan pra siklus seperti pada tabel di bawah ini

Tabel 4.1

Data Perkembangan Motorik Kasar Anak Melalui Permainan Maze Sketch Spider Pra Siklus

\begin{tabular}{|c|c|c|c|c|c|c|c|c|c|c|}
\hline \multirow{2}{*}{ No. } & \multirow{2}{*}{$\begin{array}{l}\text { Nama } \\
\text { Anak }\end{array}$} & \multicolumn{7}{|c|}{ Indikator } & \multirow{2}{*}{$\begin{array}{l}\text { Total } \\
\text { Skor }\end{array}$} & \multirow{2}{*}{$\begin{array}{c}\text { Presentase } \\
\%\end{array}$} \\
\hline & & 1.1 & 1.2 & 2.1 & 2.2 & 2.3 & 3.1 & 3.2 & & \\
\hline 1. & An & 2 & 2 & 2 & 2 & 1 & 2 & 1 & 12 & $43 \%$ \\
\hline 2. & $\mathrm{Za}$ & 2 & 2 & 2 & 1 & 2 & 2 & 1 & 12 & $43 \%$ \\
\hline 3. & $\mathrm{Ka}$ & 4 & 3 & 3 & 3 & 2 & 2 & 3 & 20 & $72 \%$ \\
\hline 4. & $\mathrm{Da}$ & 2 & 1 & 2 & 2 & 1 & 2 & 1 & 11 & $39 \%$ \\
\hline 5. & $\mathrm{Sa}$ & 1 & 2 & 3 & 2 & 3 & 2 & 3 & 16 & $57 \%$ \\
\hline 6. & $\mathrm{Fa}$ & 1 & 1 & 1 & 2 & 1 & 1 & 1 & 8 & $29 \%$ \\
\hline
\end{tabular}




\begin{tabular}{|c|c|c|c|c|c|c|c|c|c|c|}
\hline 7. & $\mathrm{Bi}$ & 1 & 1 & 1 & 1 & 2 & 1 & 1 & 8 & $29 \%$ \\
\hline 8. & $\mathrm{Fd}$ & 3 & 2 & 2 & 2 & 1 & 2 & 1 & 13 & $46 \%$ \\
\hline 9. & $\mathrm{Ko}$ & 2 & 1 & 2 & 3 & 3 & 3 & 2 & 16 & $57 \%$ \\
\hline 10. & $\mathrm{Nh}$ & 2 & 3 & 2 & 2 & 1 & 2 & 1 & 13 & $46 \%$ \\
\hline 11. & $\mathrm{Na}$ & 2 & 3 & 2 & 3 & 3 & 3 & 2 & 18 & $64 \%$ \\
\hline 12 & $\mathrm{Na}$ & 2 & 2 & 2 & 2 & 1 & 2 & 1 & 12 & $43 \%$ \\
\hline 13. & $\mathrm{Ry}$ & 1 & 1 & 2 & 2 & 1 & 1 & 1 & 9 & $32 \%$ \\
\hline 14. & $\mathrm{Yd}$ & 2 & 1 & 3 & 3 & 2 & 2 & 1 & 14 & $50 \%$ \\
\hline 15. & $\mathrm{Fi}$ & 1 & 2 & 3 & 2 & 3 & 1 & 2 & 14 & $50 \%$ \\
\hline \multicolumn{10}{|c|}{ Rata-rata presentase } \\
\hline
\end{tabular}

Presentase $=\frac{\sum \text { Skor yang diperoleh anak }}{\sum \text { Nilai indikator }} \times 100 \%$

Keterangan :

a. Berkembang sangat baik (76\%-100\%)

b. Berkembang sesuai harapan $(51 \%-75 \%)$

c. Mulai berkembang $(26 \%-50 \%)$

d. Belum berkembang $(1 \%-25 \%)$

Berdasarkan pengamatan peneliti pada pra siklus ini, dapat dilihat bahwa hasil penilaian anak pada perkembangan motorik kasar anak melalui permainan maze sketch spider ada 13 yang mendapatkan hasil di bawah 60\% dan 2 anak mendapatkan hasil di atas $60 \%$.

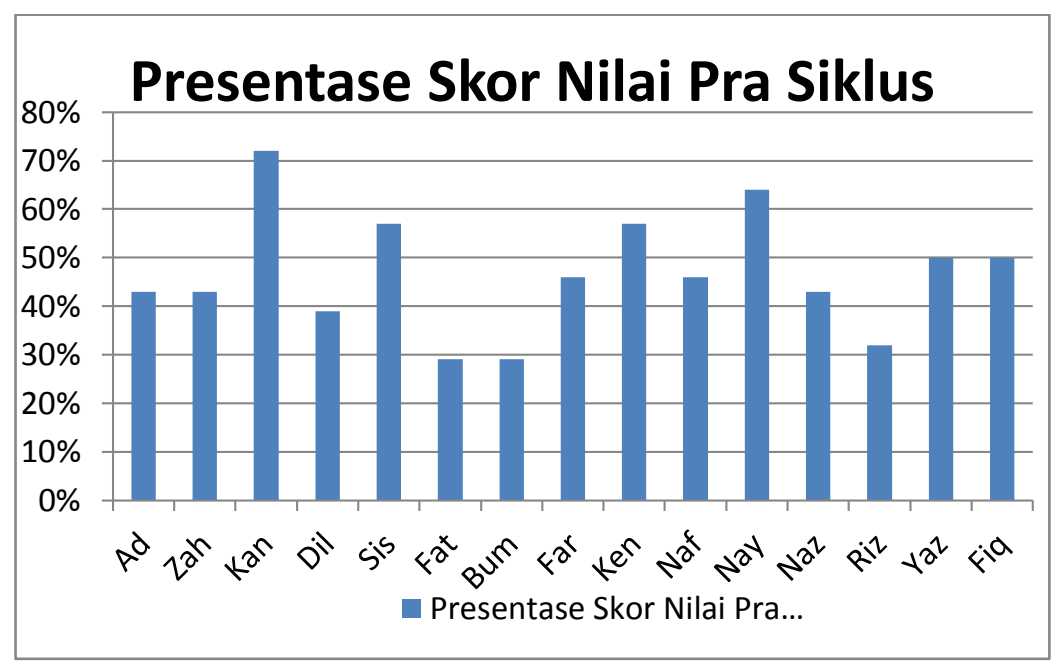

Grafik 4.1 
Grafik Perkembangan Motorik Kasar Anak Melalui Permainan Maze Sketch Spider Pra Siklus

Setelah dilaksanakan penelitian pra siklus, hasil yang didapatkan peserta didik di bawah $60 \%$ sebanyak 13 anak dan di atas 60\% sebanyak 2 anak. Berdasarkan data tersebut, total skor rata-rata perkembangan motorik kasar anak kelompok B1 TK Bunga Bangsa 2 sebanyak $47 \%$ maka hasil penelitian pra siklus belum mencapai tingkat keberhasilan 75\%. Oleh karena itu, peneliti perlu melakukan penelitian pada siklus I.

\section{Pembahasan Siklus I}

Berdasarkan pengamatan hasil siklus I, didapati peningkatan kemampuan motorik kasar anak. Pengamatan dilakukan dengan menggunakan instrument penilaian berupa lembar observasi. Berikut data perkembangan anak pada kegiatan siklus I seperti pada tabel di bawah ini.

Tabel 4.2

Data Perkembangan Motorik Kasar Anak

Melalui Permainan Maze Sketch Spider Siklus I

\begin{tabular}{|c|c|c|c|c|c|c|c|c|c|c|}
\hline \multirow{2}{*}{ No. } & Nama & \multicolumn{7}{|c|}{ Indicator } & Total & Presentase \\
\cline { 3 - 11 } & Anak & $\mathbf{1 . 1}$ & $\mathbf{1 . 2}$ & $\mathbf{2 . 1}$ & $\mathbf{2 . 2}$ & $\mathbf{2 . 3}$ & $\mathbf{3 . 1}$ & $\mathbf{3 . 2}$ & Skor & $\%$ \\
\hline 1. & $\mathrm{An}$ & 2 & 3 & 2 & 3 & 2 & 3 & 2 & 17 & $61 \%$ \\
\hline 2. & $\mathrm{Za}$ & 2 & 3 & 2 & 2 & 2 & 2 & 2 & 15 & $54 \%$ \\
\hline 3. & $\mathrm{Ka}$ & 4 & 3 & 3 & 3 & 2 & 3 & 4 & 22 & $79 \%$ \\
\hline 4. & $\mathrm{Da}$ & 2 & 2 & 2 & 3 & 2 & 2 & 2 & 15 & $54 \%$ \\
\hline
\end{tabular}




\begin{tabular}{|c|c|c|c|c|c|c|c|c|c|c|}
\hline 5. & $\mathrm{Sa}$ & 2 & 2 & 3 & 2 & 3 & 3 & 3 & 18 & $64 \%$ \\
\hline 6. & $\mathrm{Fa}$ & 1 & 2 & 1 & 2 & 2 & 1 & 2 & 11 & $39 \%$ \\
\hline 7. & $\mathrm{Bi}$ & 2 & 1 & 1 & 2 & 2 & 1 & 2 & 11 & $39 \%$ \\
\hline 8. & $\mathrm{Fd}$ & 3 & 3 & 2 & 2 & 2 & 2 & 2 & 16 & $57 \%$ \\
\hline 9. & $\mathrm{Ko}$ & 2 & 2 & 3 & 3 & 3 & 3 & 3 & 19 & $68 \%$ \\
\hline 10. & $\mathrm{Nh}$ & 3 & 3 & 2 & 2 & 2 & 2 & 2 & 16 & $57 \%$ \\
\hline 11. & $\mathrm{Na}$ & 3 & 3 & 3 & 3 & 3 & 3 & 3 & 21 & $75 \%$ \\
\hline 12 & $\mathrm{Na}$ & 2 & 3 & 2 & 2 & 2 & 3 & 2 & 16 & $57 \%$ \\
\hline 13. & $\mathrm{Ry}$ & 2 & 2 & 2 & 2 & 2 & 2 & 2 & 12 & $43 \%$ \\
\hline 14. & $\mathrm{Yd}$ & 2 & 2 & 3 & 3 & 3 & 2 & 2 & 17 & $61 \%$ \\
\hline 15. & $\mathrm{Fi}$ & 2 & 2 & 3 & 3 & 3 & 2 & 2 & 17 & $61 \%$ \\
\hline
\end{tabular}

$$
\text { Presentase }=\frac{\sum \text { Skor yang diperoleh anak }}{\sum \text { Nilai indikator }} \times 100 \%
$$

Keterangan :

1. Berkembang sangat baik $(76 \%-100 \%)$

2. Berkembang sesuai harapan $(51 \%-75 \%)$

3. Mulai berkembang $(26 \%-50 \%)$

4. Belum berkembang $(1 \%-25 \%)$

Berdasarkan pengamatan peneliti pada siklus I, dapat dilihat bahwa hasil penilaian anak pada perkembangan motorik kasar anak melalui permainan maze sketch spider ada 8 yang mendapatkan hasil di bawah $60 \%$ dan 7 anak mendapatkan hasil di atas $60 \%$.

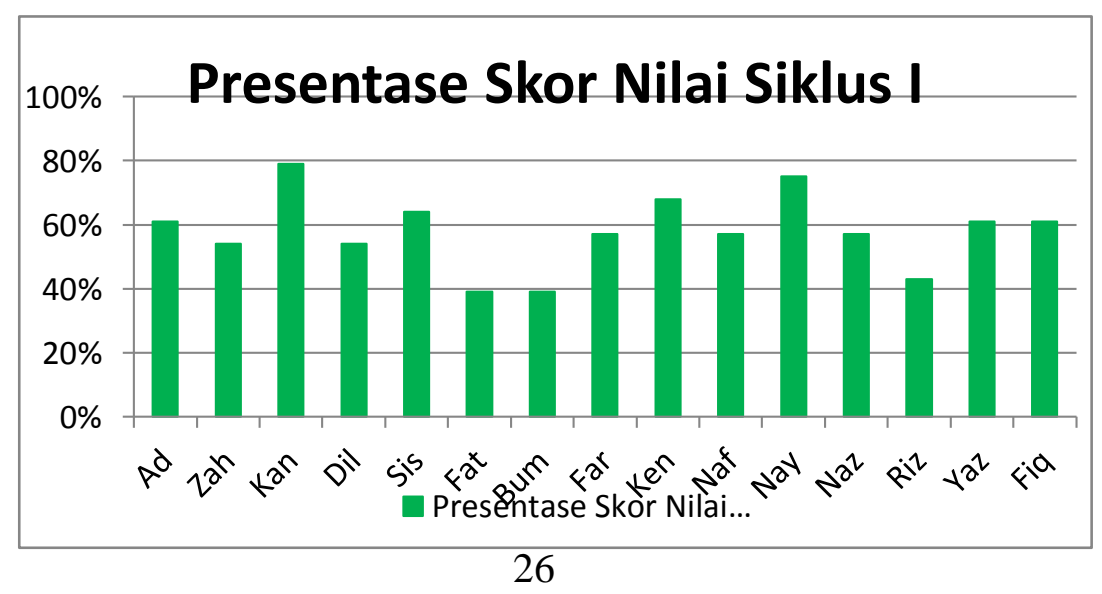




\section{Grafik 4.2}

\section{Grafik Perkembangan Motorik Kasar Anak}

\section{Melalui Permainan Maze Sketch Spider Siklus I}

Setelah dilaksanakan penelitian siklus I, hasil yang didapatkan peserta didik di bawah $70 \%$ sebanyak 8 anak dan di atas $60 \%$ sebanyak 7 anak. Berdasarkan data tersebut, total skor rata-rata perkembangan motorik kasar anak kelompok B1 TK Bunga Bangsa 2 sebanyak $58 \%$ maka hasil penelitian pra siklus belum mencapai tingkat keberhasilan $75 \%$. Oleh karena itu, peneliti perlu melakukan penelitian pada siklus selanjutnya atau siklus II.

\section{Pembahasan Siklus II}

Berdasarkan pengamatan siklus II, didapati peningkatan kemampuan motorik kasar anak. Pengamatan dilakukan dengan menggunakan instrument penilaian berupa lembar observasi. Berikut data perkembangan anak pada kegiatan siklus II seperti pada tabel di bawah ini:

Tabel 4.3

Data Perkembangan Motorik Kasar Anak Melalui Permainan Maze Sketch Spider Siklus II

\begin{tabular}{|c|c|c|c|c|c|c|c|c|c|c|}
\hline \multirow{2}{*}{ No } & Nama & \multicolumn{7}{|c|}{ Indikator } & Total & Presentase \\
& Anak & $\mathbf{1 . 1}$ & $\mathbf{1 . 2}$ & $\mathbf{2 . 1}$ & $\mathbf{2 . 2}$ & $\mathbf{2 . 3}$ & $\mathbf{3 . 1}$ & $\mathbf{3 . 2}$ & Skor & $\%$ \\
\hline 1. & $\mathrm{An}$ & 3 & 4 & 3 & 4 & 3 & 4 & 3 & 24 & $86 \%$ \\
\hline 2. & $\mathrm{Za}$ & 3 & 3 & 3 & 3 & 3 & 3 & 3 & 21 & $75 \%$ \\
\hline 3. & $\mathrm{Ka}$ & 4 & 4 & 3 & 3 & 3 & 4 & 4 & 25 & $89 \%$ \\
\hline 4. & $\mathrm{Da}$ & 3 & 3 & 3 & 3 & 3 & 3 & 3 & 21 & $75 \%$ \\
\hline 5. & $\mathrm{Sa}$ & 3 & 3 & 3 & 3 & 3 & 3 & 3 & 21 & $75 \%$ \\
\hline
\end{tabular}




\begin{tabular}{|c|c|c|c|c|c|c|c|c|c|c|}
\hline 6. & $\mathrm{Fa}$ & 3 & 3 & 3 & 3 & 3 & 3 & 3 & 21 & $75 \%$ \\
\hline 7. & $\mathrm{Bi}$ & 3 & 3 & 3 & 3 & 3 & 3 & 3 & 21 & $75 \%$ \\
\hline 8. & $\mathrm{Fd}$ & 3 & 3 & 3 & 3 & 3 & 3 & 3 & 21 & $75 \%$ \\
\hline 9. & $\mathrm{Ko}$ & 3 & 3 & 3 & 3 & 4 & 3 & 3 & 22 & $79 \%$ \\
\hline 10. & $\mathrm{Nh}$ & 3 & 3 & 3 & 3 & 3 & 3 & 3 & 21 & $75 \%$ \\
\hline 11. & $\mathrm{Na}$ & 3 & 4 & 3 & 3 & 3 & 3 & 3 & 22 & $79 \%$ \\
\hline 12 & $\mathrm{Na}$ & 3 & 3 & 3 & 3 & 3 & 4 & 3 & 22 & $79 \%$ \\
\hline 13. & $\mathrm{Ry}$ & 3 & 3 & 3 & 3 & 3 & 3 & 3 & 21 & $75 \%$ \\
\hline 14. & $\mathrm{Yd}$ & 3 & 3 & 3 & 3 & 3 & 3 & 3 & 21 & $75 \%$ \\
\hline 15. & $\mathrm{Fi}$ & 3 & 3 & 3 & 3 & 3 & 3 & 3 & 21 & $75 \%$ \\
\hline \multicolumn{10}{|c|}{ Rata-rata presentase } \\
\hline
\end{tabular}

$$
\text { Presentase }=\frac{\sum \text { Skor yang diperoleh anak }}{\sum \text { Nilai indikator }} \times 100 \%
$$

Keterangan :
a. Berkembang sangat baik $(76 \%-100 \%)$
b. Berkembang sesuai harapan $(51 \%-75 \%)$
c. Mulai berkembang $(26 \%-50 \%)$
d. Belum berkembang $(1 \%-25 \%)$

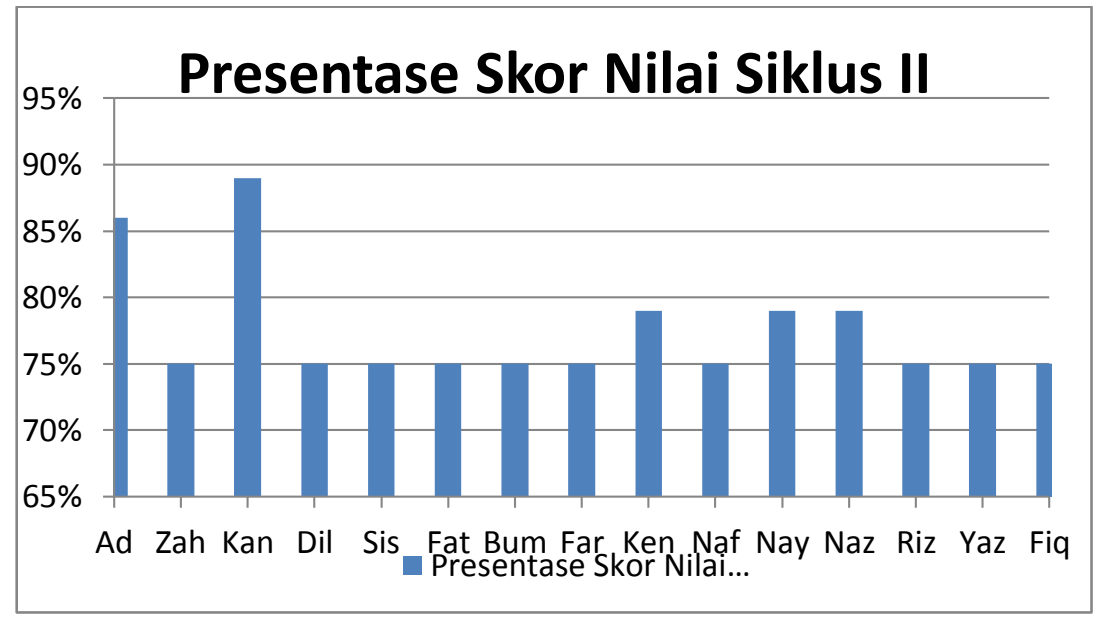

\section{Grafik 4.3}

Grafik Perkembangan Motorik Kasar Anak Melalui Permainan Maze Sketch Spider Siklus II 
Setelah dilaksanakan penelitian siklus II, hasil yang didapatkan peserta didik sudah mencapai skor nilai di atas 75\% sebanyak 15 anak. Pada siklus II terjadinya peningkatan yang signifikan dari siklus I karena hasil refleksi yang dilakukan dan masukan dari guru kelas atau kolaborator. Pada siklus II peneliti menggunakan permainan maze dengan menambah gerakan yang lebih variatif lagi.

Berdasarkan data tersebut, total skor rata-rata perkembangan motorik kasar anak siklus II kelompok B1 TK Bunga Bangsa 2 sebanyak 77\%, maka hasil penelitian di siklus II ini tidak dilanjutkan ke siklus berikunya karena skor nilai yang di capai anak sudah melewati kriteria yang telah ditentukan.

\section{Perbandingan Data Pra}

\section{Siklus, Siklus I, dan Siklus II}

Berikut merupakan data tabel dan grafik perbandingan peningkatan motorik kasar anak yang telah diamati mulai dari pra siklus, siklus I dan siklus II diantaranya:

\section{Tabel 4.4}

Perbandingan Hasil Presentase Perkembangan Motorik Kasar Anak Melalui Permainan Maze Sketch Spider

Pra Siklus, Siklus I, dan Siklus II

\begin{tabular}{|c|c|c|c|c|}
\hline No. & Nama Anak & Pra Siklus & Siklus I & Siklus II \\
\hline 1. & $\mathrm{An}$ & $43 \%$ & $61 \%$ & $86 \%$ \\
\hline 2. & $\mathrm{Za}$ & $43 \%$ & $54 \%$ & $75 \%$ \\
\hline 3. & $\mathrm{Ka}$ & $72 \%$ & $79 \%$ & $89 \%$ \\
\hline 4. & $\mathrm{Da}$ & $39 \%$ & $54 \%$ & $75 \%$ \\
\hline 5. & $\mathrm{Sa}$ & $57 \%$ & $64 \%$ & $75 \%$ \\
\hline 6. & $\mathrm{Fa}$ & $29 \%$ & $39 \%$ & $75 \%$ \\
\hline 7. & $\mathrm{Bi}$ & $29 \%$ & $39 \%$ & $75 \%$ \\
\hline
\end{tabular}




\begin{tabular}{|c|c|c|c|c|}
\hline 8. & $\mathrm{Fd}$ & $46 \%$ & $57 \%$ & $75 \%$ \\
\hline 9. & $\mathrm{Ko}$ & $57 \%$ & $68 \%$ & $79 \%$ \\
\hline 10. & $\mathrm{Nh}$ & $46 \%$ & $57 \%$ & $75 \%$ \\
\hline 11. & $\mathrm{Na}$ & $64 \%$ & $75 \%$ & $79 \%$ \\
\hline 12. & $\mathrm{Na}$ & $43 \%$ & $57 \%$ & $79 \%$ \\
\hline 13. & $\mathrm{Ry}$ & $32 \%$ & $43 \%$ & $75 \%$ \\
\hline 14. & $\mathrm{Yd}$ & $50 \%$ & $61 \%$ & $75 \%$ \\
\hline 15. & $\mathrm{Fi}$ & $50 \%$ & $61 \%$ & $75 \%$ \\
\hline \multicolumn{2}{|l|}{ Rata-Rata Presentase } & $\mathbf{4 7 \%}$ & $\mathbf{5 8 \%}$ & $\mathbf{7 7 \%}$ \\
\hline
\end{tabular}

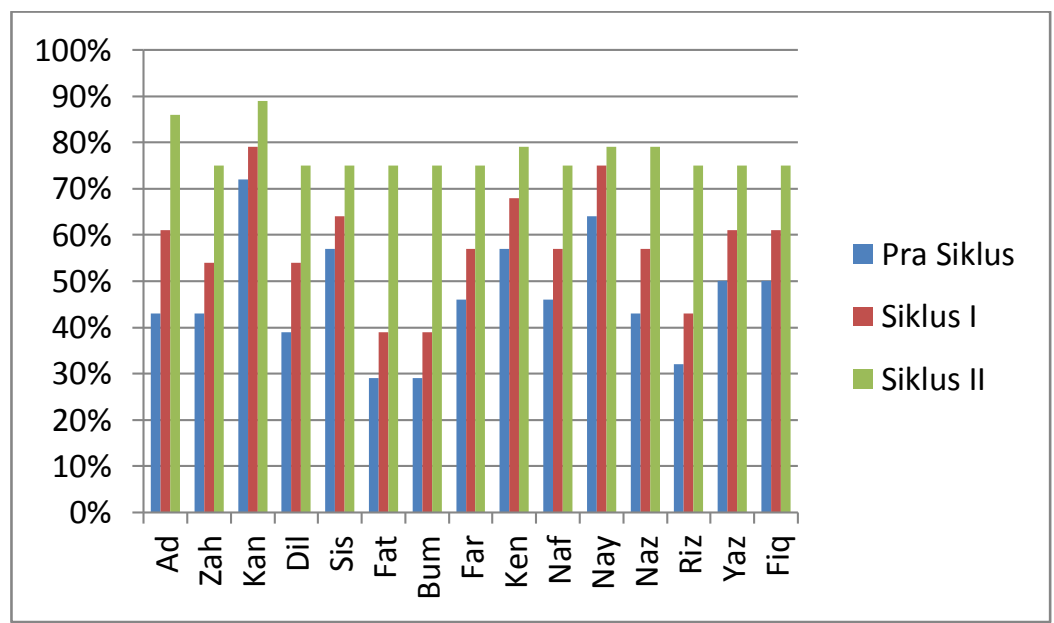

Grafik 4.4

Perbandingan Hasil Presentase Perkembangan Motorik Kasar Anak Melalui

Permainan Maze Sketch Spider Pra Siklus, Siklus I, dan Siklus II

Perbandingan mulai dari pra siklus, siklus I, dan siklus II terlihat sangat jelas peningkatannya. Peningkatan dari pra siklus ke siklus I meningkat beberapa persen, siklus I ke siklus II meningkat pula beberapa persen dan pada siklus II penelitian di hentikan karena peningkatan motorik kasar anak sudah mencapai nilai standar keberhasilan penelitian. Berikut dibawah ini merupakan hasil perbandingan dari pra siklus, siklus I, dan siklus II, yaitu: 


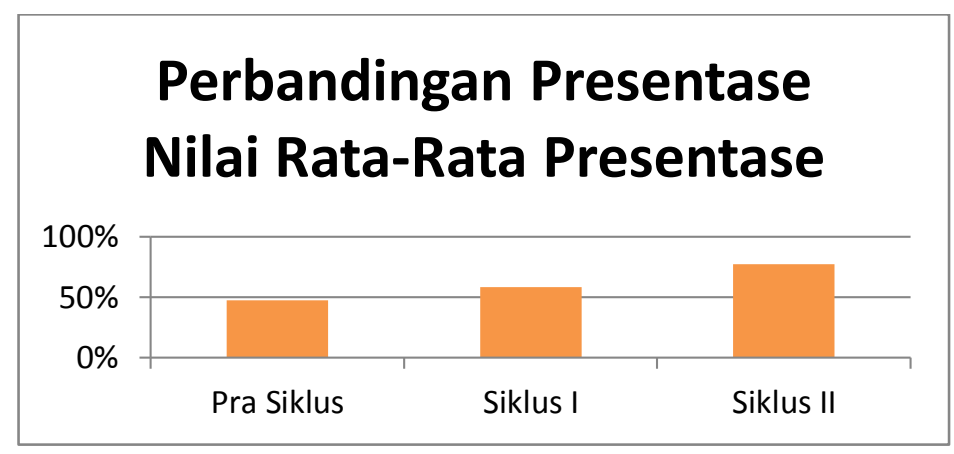

Grafik 4.5

Nilai Rata-Rata Presentase Kelas

Pra Siklus, Siklus I, Siklus II

Penelitian tindakan kelas yang telah penulis laksanakan pada tiap siklus, dan berdasarkan data pada tabel dan grafik di atas nampak bahwa ada peningkatan yang seignifikan dalam peningkatan motorik kasar anak melalui permainan maze sketch spider.

Kegiatan pembelajaran pada saat pra siklus, tingkat perkembangan kemampuan anak didik dalam permulaan mendapat nilai rata-rata kelas $47 \%$. Setelah dilaksanakan kegiatan pembelajaran siklus I melalui berbagai permainan motorik kasar terutama permainan maze sketch spider yang dilaksanakan setiap pertemuan pembelajaran terlihat lebih efektif dan mengalami peningkatan kemampuan anak dengan nilai rata-rata kelas pada siklus I meningkat menjadi $58 \%$ tetapi peningkatan dari pra siklus ke siklus I masih belum maksimal. Peningkatan yang signifikan terlihat setelah melakukan siklus II, nilai rata-rata kelas meningkat dari $58 \%$ pada siklus I menjadi $77 \%$ pada siklus II.

Berdasarkan fakta dan data tersebut, nilai anak didik dalam peningkatan kemampuan motorik kasar anak melalui permainan maze sketch spider menunjukkan peningkatan secara signifikan. Hal ini membuktikan bahwa perbaikan kegiatan pembelajaran pada siklus I dan siklus II melalui kegiatan 
permainan maze sketch spider mampu

meningkatkan kemampuan motorik

kasar anak didik di kelompok B1 TK

Bunga Bangsa 2 Gerogol Jaya Depok.

\section{KESIMPULAN}

1. Pada saat memainkan permainan maze sketch spider anak-anak terlihat sangat antusias dan bersemangat. Salah satu mengapa anak sangat antusias pada saat proses penelitian adalah peneliti merupakan guru tamu di TK Bunga Bangsa 2, antusias anak sangat terlihat sekali pada saat memainkan permainan tersebut. Termasuk juga permainan maze sketch spider adalah permainan baru yang belum pernah dimainkan di TK Bunga Bangsa 2, sehingga anak-anak sangat bersemangat dalam memainkannya.

2. Kegiatan pembelajaran pada saat pra siklus, tingkat perkembangan kemampuan anak didik dalam permulaan mendapat nilai rata-rata kelas $47 \%$. Setelah dilaksanakan kegiatan pembelajaran siklus I melalui permainan maze sketch spider mengalami peningkatan dengan nilai rata-rata kelas menjadi $58 \%$ tetapi peningkatan dari pra siklus ke siklus I masih belum maksimal. Peningkatan yang signifikan terlihat setelah melakukan siklus II, nilai rata-rata kelas meningkat dari $58 \%$ pada siklus I menjadi 77\% pada siklus II.

3. Kendala dan cara mengatasi hambatan yang dihadapai saat penerapan permainan maze skerch spider di kelompok B1 TK Bunga Bangsa 2 Gerogol Jaya Depok, diantaranya:

a. Ruang kelas yang penuh sekat dan terbatas juga tempatnya salah satu kendala yang dihadapai pada saat penelitian, 
maka peneliti dan guru menyiasati lorong di luar kelas untuk menerapkan permainan maze sketch spider.

b. Media permainan maze sketch spider terbuat dari ketas dan solatip, bila terkena air akan merusak permainan maze tersebut, pada saat bermian maze anak tidak dianjurkan membawa botol air minum.

c. Tidak bisa digunakan di lapangan yang permukaannya tidak rata, karena akan membuat bentuk permainan maze itu rusak. Permainan dialokasikan di lorong depan kelas kelompok B1. Pada saat bermainpn tidak dianjurkan menggunakan sepatu agar permainan maze tidak robek.

\section{DAFTAR PUSTAKA}

Apriani, Dian. (2016) Penerapan Permainan Tradisional Engklek Untuk Meningkatkan Kemampuan Motorik Kasar Anak Kekompok B Ra Al-Hidayah 2 Tarik Sidoarjo.

Bambang, S., Sumantri, Titi, C. (2016). Metode Pengembangan Fisik. Jakarta: Universitas Terbuka.

Endah Sudarmilah, Pengembangan Permainan Labirin Untuk Membantu Perkembangan Motorik Anak, Jurnal Protek Vol. 03 No. 2, September 2016

Hurlock, E.B. (1978). Perkembangan Anak. Jilid 1. Jakarta: Erlangga.

Ismail, Ahmad. (2009). Education Games. Yogyakarta: Pro-U Media. Kamdhi. (). Terampil Berwicara Pembelajara Bahasa Dan Sastra Indonesia. Jakarta: PT Grasindo.

Kiram, Yanuar. (2019). Belajar Keterampilan Motorik. Jakarta: Prenadamedia Group. Laksono, K., Yuli T.E.S. (2018). Penelitian 
Tindakan Kelas Bandung: PT

Remaja Rosdakarya.

Latif, M., Zukhairina, Zubaidah R., Afandi M. (2013). Orientasi Baru

Pendidikan Anak Usia Dini: Teori

Dan Aplikasi Edisi Pertama. Jakarta: Prenadamedia Group.

Mushlih, Ahmad., Dkk. (2018). Analisis

Kebijakan PAUD (Mengungkap

Isu-Isu Menarik Seputar AUD).

Jawa Tengah: Penerbit Mangku

Bumi.

Peraturan Menteri Pendidikan dan

Kebudayaan Republik Indonesia No. 137

Tahun 2014. Standar Nasional

Pendidikan Anak Usia Dini.

Riyanto, Norman. (2018). 7 Karya 1

Buku. Banjarnegara: CV. Pelita

Gemilang Sejahtera.

Sajidan. (2008). Peningkatan

Kemampuan Guru Melaksanakan

Pembelajaran Kurikulum 2013

Melalui Supervise Akademik

Metode Kelompok Bagi Guru

Mata Pelajaran Ekonomi Di SMA
Negeri 7 Surakarta Sem. Gasal

Tahun Pelajaran 2018/2019.

Jurnal Pendidikan Dwija Utama, Vol.10

No. 42. Santoso, Ahmad. (2015).

Bimbingan \& Konseling di

Taman Kanak-Kanak. Jakarta:

Kencana.

Sudarmilah, Endah. (2016).

Pengembangan Permainan Labirin

Untuk Membantu Perkembangan

Motorik Anak. Jurnal Protek Vol.03 No.2.

Sudono, Anggani. (2000). Sumber Belajar Dan Alat Permainan Untuk Pendidikan Usai Dini. Jakarta: PT Grasindo.

Suryana, Dadan. (2016). Pendidikan Anak Usia Dini Stimulus \& Aspek Perkembangan Anak. Jakarta: Kencana.

Susanto, Ahmad. (2011). Perkembangan Anak Usia dini (Pengantar Dalam Berbagai Aspeknya). Jakarta: Kencana. 
